\title{
Effect of Various Sodium Chloride Mass Fractions on Wheat and Rye Bread Using Different Dough Preparation Techniques
}

\author{
Marta Ambrosewicz-Walacik ${ }^{*}$, Małgorzata Tańska ${ }^{2}$, Daniela Rotkiewicz ${ }^{2}$ and \\ Andrzej Piętak ${ }^{1}$ \\ ${ }^{1}$ Department of Mechatronics and IT Education, Faculty of Technical Sciences, \\ University of Warmia and Mazury in Olsztyn, Słoneczna Street 46A, PL-10-700 Olsztyn, Poland \\ ${ }^{2}$ Chair of Food Plant Chemistry and Processing, Faculty of Food Sciences, \\ University of Warmia and Mazury in Olsztyn, Cieszyński Square, PL-10-957 Olsztyn, Poland
}

Received: November 17, 2014

Accepted: November 9, 2015

\begin{abstract}
Summary
This study assessed the selected properties of bread with reduced amount of sodium chloride. The bread was made from white and wholemeal wheat flour and rye flour. The dough was prepared using three techniques: with yeast, natural sourdough or starter sourdough. Sodium chloride was added to the dough at 0, 0.5, 1.0 and $1.5 \%$ of the flour mass. The following bread properties were examined in the study: yield and volume of the loaf, moisture content, crumb firmness and porosity, and organoleptic properties. Reducing the mass fraction of added sodium chloride was not found to have considerable effect on bread yield, whereas it had a significant and variable effect on the loaf volume, and crumb firmness and porosity. Organoleptic assessment showed diverse effects of sodium chloride addition on sensory properties of bread, depending on the type of bread and the dough preparation method. Reduced mass fractions of sodium chloride changed the organoleptic properties of bread made with yeast and with starter sourdough to a greater extent than of bread prepared with natural sourdough.
\end{abstract}

Key words: wheat bread, rye bread, sodium chloride mass fraction, bread properties

\section{Introduction}

Bread is a staple food in the diet of most European countries and the United States. It is the main source of complex carbohydrate, protein, vitamin B, mineral and dietary fibre intake; this applies especially to wholemeal bread (1). A decrease in bread consumption in Europe can be seen in the past few years; today approx. $170 \mathrm{~g}$ of bread per capita is consumed daily. Despite this, it is still regarded as an important source of sodium chloride in the human diet (2). A high level of bread consumption considerably contributes to exceeding the daily dose of salt of $5.8 \mathrm{~g}$, recommended by the USA National Academy of Medicine, formerly Institute of Medicine (3), equivalent to $2.3 \mathrm{~g}$ of sodium (4). According to Brown et al. (5), the physiological daily dose of sodium $(<0.6 \mathrm{~g})$ is exceeded by consumers all over the world. Salt consumption in the European and North American diet is believed to depend on the amount of salt added to the most frequently consumed processed food (75\% of total consumption), which also includes cereal products, such as bread. Daily consumption of salt in most European countries ranges from 8 to $11 \mathrm{~g}$ per capita (6). According to the European Commission Report (7), the lowest consumption of salt (6.37.3 g per day) was recorded in Germany, Bulgaria, Cyprus and Lithuania, and the highest (13.6 g per day) in the Czech Republic. Such a high consumption of salt was also observed in Slovenia, Hungary and Portugal (12.3-12.7 g per day). According to the report, more salt is usually consumed by males than by females. 
Salt, as a dough ingredient, has a beneficial effect on the properties of gluten, dough properties and bread taste $(8-10)$. However, considering its health effects, it is believed that its consumption should be reduced. Excessive amounts of consumed salt are believed to contribute to elevated arterial blood pressure, thereby increasing the risk of stroke, heart failure, cardiac infarction, renal and gastric diseases, obesity and osteoporosis $(4,8,10,11)$. The mass fraction of salt added during white bread making in European countries is varied: for example, in Portugal it is 1.67 , in the UK 1.01 and in the Netherlands $\leq 1.8 \%$ $(12,13)$. However, the lower dose of salt in food raises the producers' concern that consumers may not accept products with a less distinctive taste (14). Dötsch et al. (15) and Girgis et al. (16) suggested that sodium chloride content in bread should be reduced gradually, which will help consumers to become accustomed to the change of taste, or which will make the change of taste imperceptible. Furthermore, Noort et al. (17) have shown that in order to reduce the amount of salt without the loss of saltiness intensity, an inhomogeneous distribution of salt in bread can be used. However, considering the fact that consumers eat bread with other food, such as salty meat or cheese, or sweet jams and honey, it is believed that an absence of salt in bread would not affect considerably their taste sensations.

Appreciating the need to reduce the sodium chloride content in the diet, the aim of this study is to determine the effect of a reduced sodium chloride content on yield, volume, crumb properties and organoleptic properties of bread.

\section{Materials and Methods}

\section{Flour analysis}

Four types of flour were used to make the bread: white wheat flour (type 650 , ash content $0.63 \%$ ), wholemeal wheat flour (type 2000, ash content $1.95 \%$ ), white rye flour (type 720 , ash content $0.70 \%$ ) and wholemeal rye flour (type 2000, ash content $1.94 \%$ ). The following properties of the flour types were characterised: moisture content (18), water absorption (19), falling number (20), wet gluten content (21) and Zeleny sedimentation value (22). Each analysis was conducted in triplicate. Potable grade water was used in the study, as well as edible sodium chloride (Solino S.A., Legnica, Poland), pressed yeast (Lesaffre, Legnica, Poland) and baking starter sourdough (SAF-LEVAIN LV1; Lesaffre, Marcq-en Baroeul, France).

Water absorption was determined according to a method of Gould et al. (19). A mass of $3 \mathrm{~g}$ of the flour sample was weighed into a centrifugal tube, $30 \mathrm{~mL}$ of distilled water were added and mixed for $30 \mathrm{~s}$. The sample was allowed to hydrate for $2 \mathrm{~h}$ at room temperature. This was followed by centrifugation using a benchtop centrifuge (type 5417R; Eppendorf AG, Hamburg, Germany) at $25000 \times g$ for $10 \mathrm{~min}$. The supernatant was discarded and the hydrated sample was weighed.

\section{Baking experiment}

The dough was prepared by the addition of $0.0,0.5$, 1.0 and $1.5 \%$, by mass, of sodium chloride to the flour using three techniques: (i) with baker's yeast Saccharomy- ces cerevisiae ( $3 \%$ of flour mass). The dough with yeast was prepared with the one-phase method. All ingredients were mixed and the dough was then fermented for $2 \mathrm{~h}$ and kneaded for $80 \mathrm{~min}$ (white wheat dough) or for $1 \mathrm{~h}$ (wholemeal wheat, and white and wholemeal rye dough); (ii) with natural sourdough (30\% of dough mass). Dough with natural sourdough was prepared using a multiphase method for four days. In this method, a predetermined amount of flour was added daily to the dough, which was fermented for $24 \mathrm{~h}$ at $30^{\circ} \mathrm{C}$ and $(85 \pm 2) \%$ relative humidity in a proofing chamber (type PL 10; Warmia, Grudziądz, Poland); and (iii) with starter sourdough. Starter SAF Levain LV1 (Lesaffre) containing a mixture of Lactobacillus casei and Lactobacillus brevis bacterial cultures (2 \% in total) with Saccharomyces chevalieri yeast (98\%) was used. Dough was prepared using a two-phase method. The first step was the preparation of starter sourdough by using baking culture starter (1\% of total flour mass), $50 \%$ of the total amount of flour and $75 \%$ of the total amount of water. These ingredients were carefully mixed, then allowed to ferment for $24 \mathrm{~h}$ at $30^{\circ} \mathrm{C}$ with continuous mixing using a laboratory water bath shaker (type 357; Elpan, Lubawa, Poland). Bread dough was prepared by adding the rest of the flour (50\%) and water (25 $\%$ ), and sodium chloride. The dough was fermented for $2 \mathrm{~h}$.

Bread with $1.5 \%$ sodium chloride was used as the control in each of the dough preparation techniques. Each type of bread was baked in triplicate.

All types of dough were mixed in a laboratory dough kneading machine (GM-2; ZBPP, Bydgoszcz, Poland). Dough was fermented in a proofing chamber (type PL 10; Warmia) at $30{ }^{\circ} \mathrm{C}$ and $(85 \pm 2) \%$ relative humidity. The bread was baked in an electric laboratory oven (type PL 10; Warmia) at $230^{\circ} \mathrm{C}$ for $30 \mathrm{~min}$ (wheat bread) or $35 \mathrm{~min}$ (rye bread).

\section{Bread quality}

The quality of bread was analysed $24 \mathrm{~h}$ after baking and the following properties were assessed: yield, loaf volume, and elasticity and porosity of the crumb.

In order to determine the bread yield, the dough yield was calculated as the amount of dough obtained from 100 mass parts of flour with the moisture content of $15 \%$, expressed in mass percentage (23). The mass of the dough prepared for baking was then determined and the mass of cooled down bread was determined after baking. The bread yield was calculated from the following formula:

$$
Y(\text { bread })=\frac{m(\text { bread }) \cdot Y(\text { dough })}{m(\text { dough })}
$$

where $Y$ (bread) is the bread yield in \%, $Y$ (dough) is the dough yield in $\%, m$ (dough) is the mass of dough ready for baking in $g$ and $m$ (bread) is the mass of cooled down bread in $\mathrm{g}$. Loaf volume of $100 \mathrm{~g}$ was measured by seed displacement method (23).

Elasticity of crumb was measured with a universal testing machine (type 4301; Instron Corp., Canton, MA, USA) and expressed as the force necessary to cause elastic deformation of a $2.5-\mathrm{cm}$ cube cut out of the central part of a loaf (24). 
Porosity of crumb was measured with a Digital Image Analysis (DIA) set (equipped with lights, camera, and a computer program) based on photographs of $1.5 \mathrm{~cm}$ thick slices cut out of the central part of a loaf and expressed in percentage of total cell area per total measured area (25). The light source was a Kaiser RB 5004-HF High Frequency Daylight Copy Light set with $4 \times 36$ W fluorescent light tubes (colour temperature about $5400 \mathrm{~K}$; Kaiser Fototechnik GmbH \& Co.KG, Buchen, Germany). Images of bread slices were acquired with a Nikon DXM-1200 (Nikon Inc., Melville, NY, USA) charge-coupled device (CCD) colour camera at a resolution of $1280 \times 1024$ pixels. The centre of each slice was converted to grey scale and after adjusting the threshold, total cell area was determined using the LUCIA G v. 4.8 software (Laboratory Imaging, Prague, Czech Republic).

\section{Organoleptic evaluation}

The sensory attributes including crust, colour, taste, texture and general acceptance were evaluated by untrained 30-member panel, using a 5-point hedonic scale according to Watts et al. (26) with 1 representing the lowest score (dislike extremely) and 5 the highest score (like extremely).

\section{Statistical analysis}

The results of the study (three parallel repetitions) were statistically analysed with STATISTICA v. $10.0 \mathrm{PL}$ (StatSoft, Cracow, Poland) (27). In order to identify the significance of differences between samples, a one-way analysis of variance (ANOVA) was used with Tukey's test with the critical level of significance assumed at $p \leq 0.05$.

\section{Results}

The flour used to make the bread had normal colour, taste and smell. All flour types had good baking value, which was indicated by the calculated quality parameters (Table 1). Rye flour was characterised by the highest water absorption and the lowest falling numer. The values of falling number, wet gluten yield and Zeleny sedimentation number were the highest in white wheat flour. Wet gluten yield and Zeleny sedimentation number were not characterised in white and wholemeal flour.

Table 1. Quality characteristics of flour types used for dough preparation

\begin{tabular}{|c|c|c|c|c|}
\hline \multirow{3}{*}{ Quality parameter } & \multicolumn{4}{|c|}{ Flour type } \\
\hline & \multicolumn{2}{|c|}{ Wheat } & \multicolumn{2}{|r|}{ Rye } \\
\hline & White & Wholemeal & White & Wholemeal \\
\hline$w$ (moisture) $/ \%$ & 13.4 & 14.2 & 13.0 & 13.5 \\
\hline Water absorption/\% & 17.2 & 19.4 & 19.7 & 19.9 \\
\hline Falling number/s & 450 & 319 & 275 & 258 \\
\hline$Y($ wet gluten $) / \%$ & 27.6 & 11.1 & n.d. & n.d. \\
\hline $\begin{array}{l}\text { Zeleny sedimentation } \\
\text { number } / \mathrm{cm}^{3}\end{array}$ & 42.2 & 15.7 & n.d. & n.d. \\
\hline
\end{tabular}

n.d.=not determined
It was shown that the yield of white wheat bread made with yeast and natural sourdough with a decreased addition of sodium chloride was similar in comparison with the control sample. The greatest increase in bread yield (by $2.59 \%$ ) was observed in saltless white wheat bread made with yeast (Table 2).

Table 2. Yield of bread made from different flour types with yeast, natural sourdough or starter sourdough

\begin{tabular}{|c|c|c|c|c|}
\hline \multirow{2}{*}{$\begin{array}{l}\text { Flour } \\
\text { type }\end{array}$} & \multirow{2}{*}{$\frac{w(\mathrm{NaCl})}{\%}$} & \multicolumn{3}{|c|}{$Y / \%$} \\
\hline & & Yeast & $\begin{array}{l}\text { Natural } \\
\text { sourdough }\end{array}$ & $\begin{array}{c}\text { Starter } \\
\text { sourdough }\end{array}$ \\
\hline \multirow{4}{*}{$\begin{array}{l}\text { White } \\
\text { wheat }\end{array}$} & 1.5 & $(131.4 \pm 0.7)^{\mathrm{a}}$ & $(152.8 \pm 0.6)^{a}$ & $(134.6 \pm 0.7)^{a}$ \\
\hline & 1 & $(131.1 \pm 0.4)^{\mathrm{a}}$ & $(153.4 \pm 0.2)^{\mathrm{a}}$ & $(137.8 \pm 0.3)^{\mathrm{b}}$ \\
\hline & 0.5 & $(132.2 \pm 0.7)^{\mathrm{a}}$ & $(155.8 \pm 0.2)^{\mathrm{b}}$ & $(138.1 \pm 0.6)^{b}$ \\
\hline & 0 & $(134.8 \pm 0.4)^{\mathrm{b}}$ & $(155.2 \pm 0.2)^{\mathrm{b}}$ & $(138.2 \pm 0.2)^{\mathrm{b}}$ \\
\hline \multirow{4}{*}{$\begin{array}{l}\text { Wholemeal } \\
\text { wheat }\end{array}$} & 1.5 & $(134.4 \pm 0.7)^{\mathrm{b}}$ & $(162.1 \pm 0.5)^{\mathrm{ab}}$ & $(135.4 \pm 0.4)^{\mathrm{a}}$ \\
\hline & 1 & $(135.1 \pm 0.6)^{\mathrm{b}}$ & $(161.0 \pm 0.5)^{\mathrm{a}}$ & $(135.2 \pm 0.4)^{\mathrm{a}}$ \\
\hline & 0.5 & $(134.8 \pm 0.4)^{\mathrm{b}}$ & $(162.4 \pm 0.6)^{\mathrm{b}}$ & $(134.2 \pm 0.6)^{a}$ \\
\hline & 0 & $(133.1 \pm 0.5)^{\mathrm{a}}$ & $(161.1 \pm 0.2)^{a}$ & $(134.5 \pm 0.5)^{\mathrm{a}}$ \\
\hline \multirow{4}{*}{$\begin{array}{l}\text { White } \\
\text { rye }\end{array}$} & 1.5 & $(138.1 \pm 0.6)^{a}$ & $(180.4 \pm 0.4)^{\mathrm{b}}$ & $(140.9 \pm 0.7)^{a}$ \\
\hline & 1 & $(143.5 \pm 0.5)^{b}$ & $(180.8 \pm 0.2)^{\mathrm{b}}$ & $(142.9 \pm 0.3)^{b}$ \\
\hline & 0.5 & $(143.0 \pm 0.2)^{\mathrm{b}}$ & $(184.5 \pm 0.1)^{c}$ & $(143.0 \pm 0.4)^{\mathrm{b}}$ \\
\hline & 0 & $(145.7 \pm 0.5)^{c}$ & $(178.8 \pm 0.2)^{\mathrm{a}}$ & $(142.7 \pm 0.4)^{\mathrm{b}}$ \\
\hline \multirow{4}{*}{$\begin{array}{l}\text { Wholemeal } \\
\text { rye }\end{array}$} & 1.5 & $(142.6 \pm 0.4)^{\mathrm{a}}$ & $(177.8 \pm 0.5)^{\mathrm{a}}$ & $(144.0 \pm 0.5)^{\mathrm{a}}$ \\
\hline & 1 & $(144.3 \pm 0.4)^{\mathrm{b}}$ & $(179.4 \pm 0.2)^{\mathrm{b}}$ & $(143.7 \pm 0.4)^{\mathrm{a}}$ \\
\hline & 0.5 & $(147.0 \pm 0.6)^{c}$ & $(185.5 \pm 0.4)^{c}$ & $(144.8 \pm 0.2)^{\mathrm{b}}$ \\
\hline & 0 & $(144.8 \pm 0.6)^{\mathrm{b}}$ & $(188.3 \pm 0.5)^{\mathrm{d}}$ & $(145.3 \pm 0.6)^{c}$ \\
\hline
\end{tabular}

The values are mean \pm standard deviation

Different letters in superscript represent significant differences between mean values

A similar relationship was observed in saltless white rye bread made with yeast, whose yield was greater by $5.5 \%$ than of the control sample with the addition of 1.5 $\%$ of sodium chloride. The yield of the other samples of white rye bread prepared with natural sourdough or starter sourdough was not affected by the reduction of the mass fraction of sodium chloride. Also, the yield of all the wholemeal wheat bread loaves prepared with yeast, natural sourdough and starter sourdough was similar, regardless of the mass fraction of added sodium chloride.

Decreasing the mass fraction of sodium chloride affected the bread volume depending on the type of flour and the technique of dough preparation (Table 3).

The volume of white wheat bread made with each technique of dough preparation increased with decreasing sodium chloride content. The largest volume increase (approx. $26 \%$ compared to the control sample) was observed in saltless white wheat bread, both made with yeast and with starter sourdough (Table 3). The volume of saltless wholemeal wheat bread prepared with yeast and starter sourdough was found to decrease by 7.1 and $7.5 \%$ compared to the control sample and the sample prepared with natural sourdough, which increased by $2.4 \%$ (Table 3). The relationship between the volume of white rye bread and sodium chloride addition was inconclusive. A 
Table 3. Volume of bread loaves made from different flour types with different leavening agents

\begin{tabular}{|c|c|c|c|c|}
\hline \multirow{2}{*}{$\begin{array}{l}\text { Flour } \\
\text { type }\end{array}$} & \multirow{2}{*}{$\frac{w(\mathrm{NaCl})}{\%}$} & \multicolumn{3}{|c|}{$\mathrm{V} / \mathrm{cm}^{3}$} \\
\hline & & Yeast & $\begin{array}{l}\text { Natural } \\
\text { sourdough }\end{array}$ & $\begin{array}{c}\text { Starter } \\
\text { sourdough }\end{array}$ \\
\hline \multirow{4}{*}{$\begin{array}{l}\text { White } \\
\text { wheat }\end{array}$} & 1.5 & $(368 \pm 9)^{a}$ & $(264 \pm 6)^{a}$ & $(230 \pm 4)^{\mathrm{a}}$ \\
\hline & 1 & $(415 \pm 2)^{b}$ & $(255 \pm 4)^{\mathrm{a}}$ & $(262 \pm 2)^{b}$ \\
\hline & 0.5 & $(439 \pm 10)^{c}$ & $(272 \pm 3)^{b}$ & $(287 \pm 3)^{c}$ \\
\hline & 0 & $(462 \pm 3)^{\mathrm{d}}$ & $(296 \pm 1)^{c}$ & $(291 \pm 5)^{\mathrm{d}}$ \\
\hline \multirow{4}{*}{$\begin{array}{l}\text { Wholemeal } \\
\text { wheat }\end{array}$} & 1.5 & $(171 \pm 1)^{a}$ & $(208 \pm 4)^{a}$ & $(164 \pm 3)^{a}$ \\
\hline & 1 & $(166 \pm 5)^{\mathrm{ab}}$ & $(211.2 \pm 0.5)^{\mathrm{b}}$ & $(165 \pm 4)^{\mathrm{a}}$ \\
\hline & 0.5 & $(163 \pm 4)^{\mathrm{b}}$ & $(212 \pm 3)^{b}$ & $(159 \pm 3)^{a}$ \\
\hline & 0 & $(158 \pm 1)^{c}$ & $(213 \pm 2)^{\mathrm{b}}$ & $(152 \pm 1)^{\mathrm{b}}$ \\
\hline \multirow{4}{*}{$\begin{array}{l}\text { White } \\
\text { rye }\end{array}$} & 1.5 & $(180 \pm 3)^{\mathrm{a}}$ & $(216 \pm 1)^{a}$ & $(213.9 \pm 0.9)^{a}$ \\
\hline & 1 & $(174 \pm 1)^{b}$ & $(21.9 \pm 0.4)^{\mathrm{a}}$ & $(179 \pm 2)^{b}$ \\
\hline & 0.5 & $(174 \pm 2)^{\mathrm{b}}$ & $(221 \pm 3)^{b}$ & $(176 \pm 1)^{b}$ \\
\hline & 0 & $(172 \pm 3)^{b}$ & $(221 \pm 3)^{b}$ & $(177 \pm 1)^{\mathrm{b}}$ \\
\hline \multirow{4}{*}{$\begin{array}{l}\text { Wholemeal } \\
\text { rye }\end{array}$} & 1.5 & $(152 \pm 1)^{\mathrm{a}}$ & $(184 \pm 2)^{a}$ & $(102.6 \pm 0.1)^{a}$ \\
\hline & 1 & $(145 \pm 2)^{\mathrm{b}}$ & $(180 \pm 3)^{\mathrm{ab}}$ & $(102.8 \pm 0.9)^{a}$ \\
\hline & 0.5 & $(143 \pm 2)^{b}$ & $(180 \pm 1)^{\mathrm{ab}}$ & $(99.8 \pm 0.2)^{\mathrm{b}}$ \\
\hline & 0 & $(142 \pm 3)^{b}$ & $(179 \pm 1)^{b}$ & $(102.7 \pm 0.3)^{a}$ \\
\hline
\end{tabular}

$m($ loaf $)=100 \mathrm{~g}$

The values are mean \pm standard deviation

Different letters in superscript present significant differences between mean values

significant decrease was found of the loaf volume of bread prepared with yeast (maximum decrease by $4.1 \%$ ), while with natural sourdough maximum increase was 2.3 $\%$. The volume of white rye bread made from dough prepared with starter sourdough without the addition of sodium chloride decreased by $17 \%$ compared to the bread made with $1.5 \%$ of sodium chloride. Wholemeal wheat bread made with yeast or starter sourdough without the addition of sodium chloride had $7 \%$ smaller volume, while the volume of bread prepared with natural sourdough increased only slightly. A decrease in sodium chloride mass fraction reduced the volume of wholemeal rye bread prepared with yeast by $4-6 \%$ and of that prepared with natural sourdough by approx. $3 \%$, whereas it did not change the volume of bread made with starter sourdough (Table 3).

Firmness of bread crumb was the most affected by decreasing sodium chloride content, with the trend varying from one bread type to another (Table 4).

Yeast bread made from white wheat flour with the reduced mass fraction of sodium chloride had lower firmness. The oposite was observed for the bread sample prepared from wholemeal wheat flour. The other types of yeast bread, wholemeal wheat bread and white rye bread, had increased firmness after the reduction of the mass fraction of sodium chloride (Table 4). The firmness of rye bread prepared with natural sourdough changed similarly; moreover, the firmness of saltless wholemeal bread was found to increase threefold (as measured by the crumb compression force). Furthermore, the firmness of wheat bread made from white and wholemeal flour with
Table 4. Firmness of bread crumbs made from different flour types with different leavening agents

\begin{tabular}{|c|c|c|c|c|}
\hline \multirow{2}{*}{$\begin{array}{l}\text { Bread } \\
\text { type }\end{array}$} & \multirow{2}{*}{$\frac{w(\mathrm{NaCl})}{\%}$} & \multicolumn{3}{|c|}{ Firmness/N } \\
\hline & & Yeast & $\begin{array}{l}\text { Natural } \\
\text { sourdough }\end{array}$ & $\begin{array}{c}\text { Starter } \\
\text { sourdough }\end{array}$ \\
\hline \multirow{4}{*}{$\begin{array}{l}\text { White } \\
\text { wheat }\end{array}$} & 1.5 & $(6.1 \pm 0.2)^{\mathrm{b}}$ & $(15.0 \pm 0.1)^{\mathrm{b}}$ & $(9.6 \pm 0.5)^{\mathrm{ab}}$ \\
\hline & 1 & $(5.8 \pm 0.1)^{\mathrm{b}}$ & $(14.8 \pm 0.3)^{\mathrm{ab}}$ & $(9.0 \pm 0.2)^{a}$ \\
\hline & 0.5 & $(5.1 \pm 0.1)^{\mathrm{b}}$ & $(14.6 \pm 0.2)^{\mathrm{a}}$ & $(9.9 \pm 0.3)^{\mathrm{b}}$ \\
\hline & 0 & $(4.7 \pm 0.1)^{\mathrm{a}}$ & $(14.5 \pm 0.2)^{\mathrm{a}}$ & $(12.0 \pm 0.1)^{\mathrm{c}}$ \\
\hline \multirow{4}{*}{$\begin{array}{l}\text { Wholemeal } \\
\text { wheat }\end{array}$} & 1.5 & $(17.3 \pm 0.1)^{\mathrm{a}}$ & $(17.0 \pm 0.1)^{c}$ & $(22.8 \pm 0.1)^{\mathrm{a}}$ \\
\hline & 1 & $(22.5 \pm 0.1)^{\mathrm{b}}$ & $(15.8 \pm 0.2)^{b}$ & $(25.7 \pm 0.1)^{\mathrm{c}}$ \\
\hline & 0.5 & $(26.2 \pm 0.2)^{c}$ & $(14.6 \pm 0.4)^{\mathrm{a}}$ & $(26.1 \pm 0.4)^{\mathrm{c}}$ \\
\hline & 0 & $(26.4 \pm 0.4)^{c}$ & $(14.5 \pm 0.4)^{\mathrm{a}}$ & $(24.3 \pm 0.3)^{\mathrm{b}}$ \\
\hline \multirow{4}{*}{ White } & 1.5 & $(13.7 \pm 0.4)^{\mathrm{a}}$ & $(8.3 \pm 0.2)^{a}$ & $(14.3 \pm 0.1)^{\mathrm{b}}$ \\
\hline & 1 & $(13.9 \pm 0.1)^{\mathrm{a}}$ & $(9.7 \pm 0.3)^{\mathrm{b}}$ & $(14.0 \pm 0.2)^{\mathrm{b}}$ \\
\hline & 0.5 & $(15.8 \pm 0.2)^{\mathrm{b}}$ & $(11.8 \pm 0.4)^{c}$ & $(13.8 \pm 0.3)^{\mathrm{a}}$ \\
\hline & 0 & $(17.8 \pm 0.3)^{c}$ & $(12.3 \pm 0.3)^{c}$ & $(13.7 \pm 0.3)^{\mathrm{a}}$ \\
\hline \multirow{4}{*}{$\begin{array}{l}\text { Wholemeal } \\
\text { rye }\end{array}$} & 1.5 & $(30.0 \pm 0.2)^{b}$ & $(9.3 \pm 0.1)^{a}$ & $(29.1 \pm 0.2)^{\mathrm{a}}$ \\
\hline & 1 & $(23.2 \pm 0.1)^{\mathrm{a}}$ & $(9.3 \pm 0.5)^{a}$ & $(29.3 \pm 0.6)^{a}$ \\
\hline & 0.5 & $(23.4 \pm 0.1)^{\mathrm{a}}$ & $(24.9 \pm 0.1)^{\mathrm{b}}$ & $(35.2 \pm 0.1)^{\mathrm{b}}$ \\
\hline & 0 & $(23.7 \pm 0.2)^{\mathrm{a}}$ & $(27.9 \pm 0.4)^{c}$ & $(39.3 \pm 0.3)^{\mathrm{c}}$ \\
\hline
\end{tabular}

The values are mean \pm standard deviation

Different letters in superscript present significant differences between mean values

natural sourdough decreased with the reduction of sodium chloride mass fraction. The firmness of white and wholemeal wheat bread and wholemeal rye bread made with starter sourdough significantly increased when sodium chloride content was reduced (Table 4).

The porosity of crumbs of wheat and rye bread depended mainly on the flour type, as well as on the technique of dough preparation (Fig. 1).

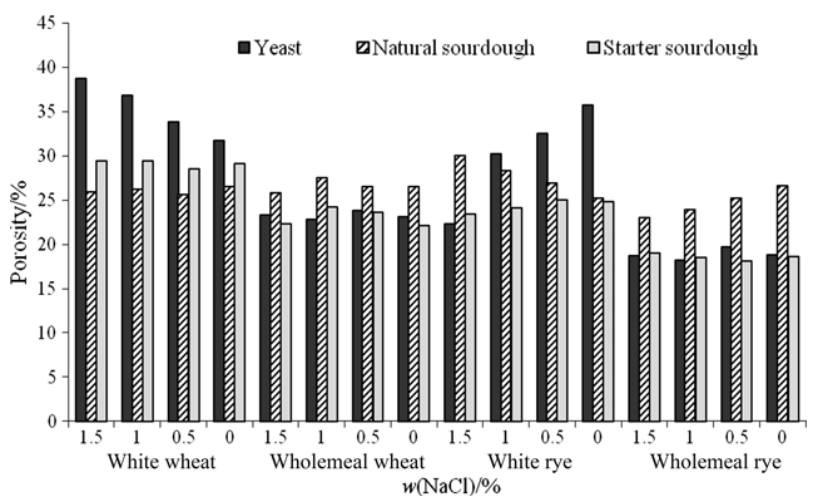

Fig. 1. Porosity of bread crumbs made with different types of flour using yeast, natural sourdough and starter sourdough

A reduced mass fraction of sodium chloride affected the porosity and appearance of crumb differently. It was found that the saltless white wheat bread prepared with baker's yeast, compared to a control sample with $1.5 \%$ sodium chloride, was characterised by tough crumb with small pores (Fig. 2). No effect of various doses of sodium 
chloride on the porosity of crumbs was observed in white wheat bread prepared with natural sourdough and starter sourdough (Fig. 2). A similar relationship was demonstrated for all wholemeal wheat bread types (Figs. 1 and 3).

$1 \mathbf{A}$

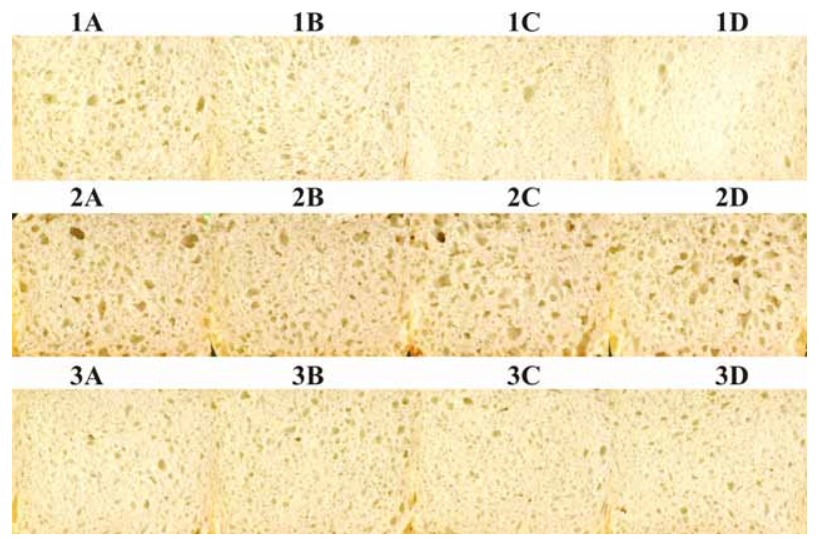

Fig. 2. Images of white wheat crumbs obtained with different techniques of dough preparation $(1-3=$ bread from dough fermented with baker's yeast, natural sourdough and starter sourdough, respectively), with different mass fractions of sodium chloride (A-D $=1.5,1,0.5$ and $0 \%$, respectively)

$1 \mathrm{~A}$
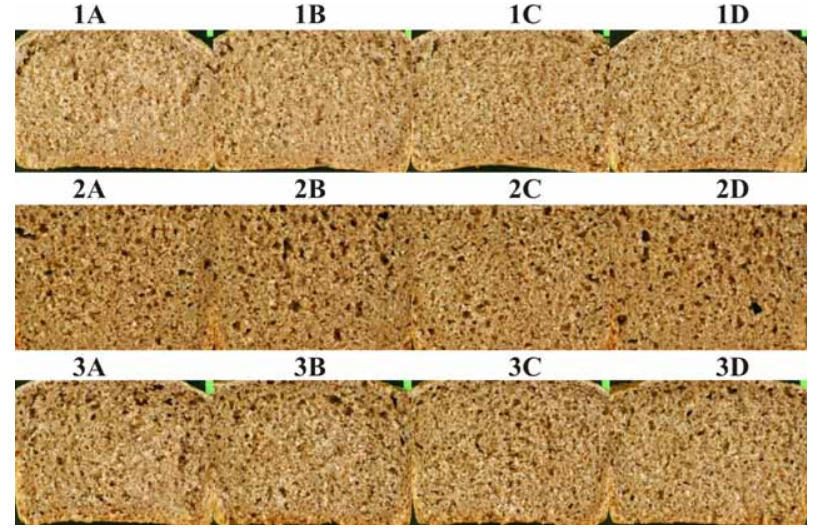

Fig. 3. Images of wholemeal wheat crumbs obtained with different techniques of dough preparation (1-3=bread from dough fermented with baker's yeast, natural sourdough and starter sourdough, respectively), with different mass fractions of sodium chloride (A-D=1.5, 1, 0.5 and $0 \%$, respectively)

Porosity of crumbs of white rye bread prepared with yeast and wholemeal rye bread made with natural sourdough increased with the decrease of sodium chloride content (Fig. 1). Moreover, the pores were of various sizes and irregular shapes (Figs. 4 and 5). The opposite relationship was observed in the white rye bread made with natural sourdough (Fig. 1). The porosity of white and wholemeal rye bread made with starter sourdough and wholemeal rye bread containing yeast did not depend on the addition of sodium chloride (Fig. 1).

Reduced mass fractions of sodium chloride changed the results of organoleptic assessments (scores for crust, colour, taste, texture and general acceptance) of bread made with yeast and bread made with starter sourdough to a greater extent than of bread prepared with natural

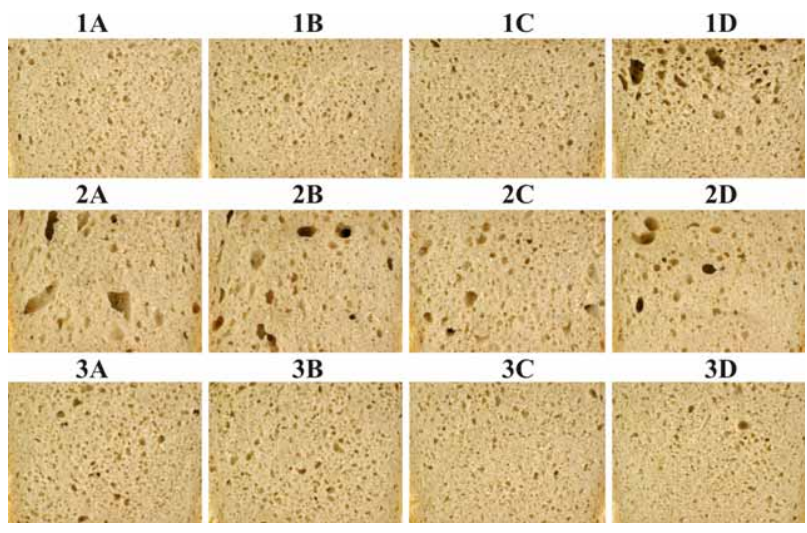

Fig. 4. Images of white rye crumbs obtained with different techniques of dough preparation (1-3=bread from dough fermented with baker's yeast, natural sourdough and starter sourdough, respectively), with different mass fractions of sodium chloride $(\mathrm{A}-\mathrm{D}=1.5,1,0.5$ and $0 \%$, respectively)

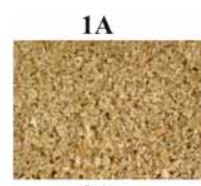

2A
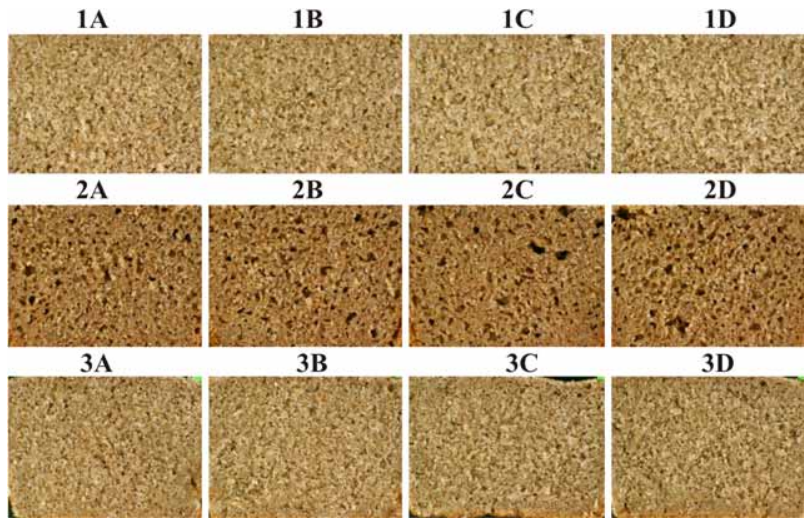

Fig. 5. Images of wholemeal rye crumbs obtained with different techniques of dough preparation (1-3=bread from dough fermented with baker's yeast, natural sourdough and starter sourdough, respectively), with different mass fractions of sodium chloride (A-D=1.5, 1, 0.5 and $0 \%$, respectively)

sourdough (Tables 5-7). The sensory properties of bread made from white wheat flour and white and wholemeal rye flour with yeast without added sodium chloride were improved (Table 5). The reduction of the mass fraction of sodium chloride did not affect the sensory properties of white and wholemeal rye bread and it had little effect on the properties of white wheat bread when dough was made with natural sourdough (Table 6). An adverse effect of reduced amount of sodium chloride was observed only in wheat bread made from wholemeal flour with natural sourdough, in which the appearance of the crust deteriorated. The reduction of the amount of sodium chloride added to the dough prepared with starter sourdough perceptibly improved the sensory properties of white wheat bread by making it taste better, while the deterioration of organoleptic properties was observed in white rye bread (Table 7).

\section{Discussion}

Wheat bread made from white flour can be baked even without the addition of sodium chloride using each 
Table 5. Organoleptic properties of bread made from different types of flour using yeast

\begin{tabular}{|c|c|c|c|c|c|c|c|c|c|c|c|c|c|c|c|c|}
\hline \multirow{4}{*}{ Organoleptic properties } & \multicolumn{16}{|c|}{ Type of flour/points } \\
\hline & \multicolumn{4}{|c|}{ White wheat } & \multicolumn{4}{|c|}{ Wholemeal wheat } & \multicolumn{4}{|c|}{ White rye } & \multicolumn{4}{|c|}{ Wholemeal rye } \\
\hline & \multicolumn{4}{|c|}{$w(\mathrm{NaCl}) / \%$} & \multicolumn{4}{|c|}{$w(\mathrm{NaCl}) / \%$} & \multicolumn{4}{|c|}{$w(\mathrm{NaCl}) / \%$} & \multicolumn{4}{|c|}{$w(\mathrm{NaCl}) / \%$} \\
\hline & 1.5 & 1.0 & 0.5 & 0.0 & 1.5 & 1.0 & 0.5 & 0.0 & 1.5 & 1.0 & 0.5 & 0.0 & 1.5 & 1.0 & 0.5 & 0.0 \\
\hline Physical appearance & 4 & 4 & 4 & 4 & 5 & 5 & 4 & 4 & 4 & 4 & 4 & 4 & 4 & 4 & 4 & 4 \\
\hline \multicolumn{17}{|l|}{ Crust } \\
\hline appearance & 4 & 4 & 5 & 5 & 4 & 4 & 4 & 4 & 4 & 4 & 4 & 4 & 4 & 4 & 4 & 4 \\
\hline colour & 4 & 4 & 4 & 4 & 4 & 4 & 4 & 4 & 4 & 4 & 4 & 5 & 4 & 4 & 4 & 4 \\
\hline thickness & 4 & 4 & 5 & 5 & 4 & 4 & 4 & 4 & 4 & 4 & 4 & 4 & 4 & 4 & 4 & 4 \\
\hline smell & 4 & 4 & 4 & 4 & 4 & 4 & 4 & 4 & 4 & 4 & 4 & 4 & 4 & 4 & 4 & 4 \\
\hline \multicolumn{17}{|l|}{ Crumb } \\
\hline appearance & 4 & 4 & 4 & 4 & 4 & 4 & 4 & 4 & 4 & 4 & 4 & 4 & 4 & 4 & 4 & 4 \\
\hline colour & 5 & 4 & 4 & 4 & 4 & 4 & 4 & 4 & 4 & 4 & 4 & 4 & 4 & 4 & 4 & 4 \\
\hline porosity & 4 & 4 & 4 & 4 & 4 & 4 & 4 & 4 & 4 & 4 & 4 & 4 & 3 & 3 & 4 & 4 \\
\hline flexibility & 5 & 5 & 4 & 4 & 4 & 4 & 4 & 4 & 4 & 4 & 4 & 4 & 3 & 3 & 3 & 3 \\
\hline Smell & 4 & 4 & 5 & 5 & 4 & 4 & 4 & 4 & 4 & 4 & 3 & 4 & 4 & 4 & 3 & 3 \\
\hline Taste & 3 & 4 & 4 & 4 & 3 & 3 & 4 & 4 & 3 & 3 & 3 & 4 & 3 & 3 & 3 & 4 \\
\hline Susceptibility to chewing & 4 & 4 & 4 & 4 & 4 & 4 & 4 & 4 & 3 & 3 & 3 & 4 & 3 & 3 & 3 & 4 \\
\hline Total & 4.08 & 4.08 & 4.17 & 4.25 & 4.08 & 4.00 & 4.00 & 4.00 & 3.83 & 3.83 & 3.75 & 4.08 & 3.67 & 3.67 & 3.67 & 3.83 \\
\hline
\end{tabular}

Table 6. Organoleptic properties of bread made from different types of flour using natural sourdough

\begin{tabular}{|c|c|c|c|c|c|c|c|c|c|c|c|c|c|c|c|c|}
\hline \multirow{4}{*}{ Organoleptic properties } & \multicolumn{16}{|c|}{ Type of flour/points } \\
\hline & \multicolumn{4}{|c|}{ White wheat } & \multicolumn{4}{|c|}{ Wholemeal wheat } & \multicolumn{4}{|c|}{ White rye } & \multicolumn{4}{|c|}{ Wholemeal rye } \\
\hline & \multicolumn{4}{|c|}{$w(\mathrm{NaCl}) / \%$} & \multicolumn{4}{|c|}{$w(\mathrm{NaCl}) / \%$} & \multicolumn{4}{|c|}{$w(\mathrm{NaCl}) / \%$} & \multicolumn{4}{|c|}{$w(\mathrm{NaCl}) / \%$} \\
\hline & 1.5 & 1.0 & 0.5 & 0.0 & 1.5 & 1.0 & 0.5 & 0.0 & 1.5 & 1.0 & 0.5 & 0.0 & 1.5 & 1.0 & 0.5 & 0.0 \\
\hline Physical appearance & 4 & 4 & 4 & 4 & 5 & 4 & 4 & 4 & 4 & 4 & 4 & 4 & 3 & 3 & 4 & 3 \\
\hline \multicolumn{17}{|l|}{ Crust } \\
\hline appearance & 4 & 4 & 4 & 5 & 5 & 5 & 4 & 4 & 4 & 4 & 4 & 4 & 4 & 4 & 4 & 4 \\
\hline colour & 4 & 5 & 5 & 4 & 5 & 5 & 4 & 4 & 4 & 4 & 4 & 4 & 4 & 4 & 4 & 4 \\
\hline thickness & 4 & 4 & 4 & 5 & 4 & 4 & 4 & 4 & 4 & 4 & 4 & 4 & 4 & 3 & 4 & 3 \\
\hline smell & 4 & 4 & 4 & 4 & 4 & 4 & 4 & 4 & 4 & 4 & 4 & 4 & 4 & 4 & 4 & 4 \\
\hline \multicolumn{17}{|l|}{ Crumb } \\
\hline appearance & 4 & 4 & 4 & 4 & 4 & 4 & 4 & 4 & 4 & 4 & 4 & 4 & 3 & 3 & 3 & 3 \\
\hline colour & 4 & 4 & 4 & 4 & 4 & 4 & 4 & 4 & 4 & 4 & 4 & 4 & 4 & 4 & 3 & 3 \\
\hline porosity & 4 & 4 & 4 & 4 & 4 & 4 & 4 & 4 & 4 & 4 & 4 & 4 & 4 & 3 & 3 & 3 \\
\hline flexibility & 4 & 4 & 4 & 4 & 4 & 4 & 4 & 4 & 4 & 4 & 4 & 4 & 3 & 3 & 3 & 3 \\
\hline Smell & 4 & 4 & 4 & 4 & 4 & 4 & 4 & 4 & 4 & 4 & 4 & 4 & 4 & 4 & 4 & 4 \\
\hline Taste & 4 & 4 & 4 & 4 & 4 & 4 & 4 & 4 & 4 & 4 & 4 & 4 & 3 & 3 & 3 & 3 \\
\hline Susceptibility to chewing & 4 & 4 & 4 & 4 & 4 & 4 & 4 & 4 & 4 & 4 & 4 & 4 & 3 & 3 & 3 & 3 \\
\hline Total & 4.00 & 4.08 & 4.08 & 4.17 & 4.25 & 4.17 & 4.00 & 4.00 & 4.00 & 4.00 & 4.00 & 4.00 & 3.58 & 3.42 & 3.50 & 3.33 \\
\hline
\end{tabular}

of the techniques of dough preparation, while wheat bread from wholemeal flour can be made without sodium chloride only when prepared with natural sourdough or starter sourdough. On the other hand, while rye bread from white flour can be prepared with a mass fraction of sodium chloride reduced to $1 \%$ when the dough is made with yeast or natural sourdough, the rye bread from wholemeal flour can be made without sodium chloride only using yeast. Lynch et al. (9) examined the effect of the mass fraction of sodium chloride ( $0,0.3,0.6$ and $1.2 \%$ ) on fermentation of wheat dough and showed that the use of a reduced amount of sodium chloride decreased the dough resistance to extension and elastic and complex moduli without affecting the liquid-to-solid ratio. The authors found that no major structural changes took place as a result of sodium chloride reduction. Moreover, they reported that with sodium chloride reduction, the changes in gas-holding capacity of the dough were observed. It 
Table 7. Organoleptic properties of bread made from different types of flour using starter sourdough

\begin{tabular}{|c|c|c|c|c|c|c|c|c|c|c|c|c|c|c|c|c|}
\hline \multirow{4}{*}{ Organoleptic properties } & \multicolumn{16}{|c|}{ Type of flour/points } \\
\hline & \multicolumn{4}{|c|}{ White wheat } & \multicolumn{4}{|c|}{ Wholemeal wheat } & \multicolumn{4}{|c|}{ White rye } & \multicolumn{4}{|c|}{ Wholemeal rye } \\
\hline & \multicolumn{4}{|c|}{$w(\mathrm{NaCl}) / \%$} & \multicolumn{4}{|c|}{$w(\mathrm{NaCl}) / \%$} & \multicolumn{4}{|c|}{$w(\mathrm{NaCl}) / \%$} & \multicolumn{4}{|c|}{$w(\mathrm{NaCl}) / \%$} \\
\hline & 1.5 & 1.0 & 0.5 & 0.0 & 1.5 & 1.0 & 0.5 & 0.0 & 1.5 & 1.0 & 0.5 & 0.0 & 1.5 & 1.0 & 0.5 & 0.0 \\
\hline Physical appearance & 3 & 3 & 3 & 4 & 4 & 4 & 4 & 5 & 2 & 2 & 3 & 3 & 5 & 5 & 5 & 5 \\
\hline \multicolumn{17}{|l|}{ Crust } \\
\hline appearance & 4 & 4 & 4 & 4 & 4 & 4 & 4 & 4 & 2 & 2 & 2 & 2 & 5 & 5 & 5 & 5 \\
\hline colour & 4 & 4 & 4 & 4 & 4 & 4 & 4 & 4 & 3 & 3 & 3 & 3 & 5 & 5 & 5 & 5 \\
\hline thickness & 3 & 3 & 3 & 4 & 4 & 4 & 4 & 4 & 2 & 2 & 2 & 2 & 5 & 5 & 5 & 5 \\
\hline smell & 4 & 4 & 4 & 4 & 5 & 5 & 5 & 5 & 3 & 3 & 3 & 4 & 5 & 5 & 5 & 5 \\
\hline \multicolumn{17}{|l|}{ Crumb } \\
\hline appearance & 4 & 4 & 3 & 4 & 4 & 4 & 4 & 4 & 3 & 3 & 3 & 3 & 4 & 5 & 5 & 4 \\
\hline colour & 3 & 3 & 3 & 3 & 5 & 5 & 5 & 5 & 3 & 3 & 3 & 3 & 5 & 5 & 5 & 5 \\
\hline porosity & 5 & 4 & 4 & 4 & 4 & 4 & 4 & 3 & 2 & 2 & 2 & 3 & 5 & 4 & 5 & 4 \\
\hline flexibility & 4 & 4 & 4 & 4 & 4 & 4 & 4 & 4 & 3 & 3 & 3 & 3 & 4 & 4 & 4 & 4 \\
\hline Smell & 3 & 4 & 4 & 4 & 4 & 4 & 4 & 4 & 4 & 4 & 4 & 4 & 5 & 4 & 5 & 5 \\
\hline Taste & 2 & 3 & 3 & 3 & 4 & 4 & 4 & 4 & 2 & 2 & 3 & 3 & 3 & 4 & 4 & 3 \\
\hline Susceptibility to chewing & 4 & 4 & 4 & 4 & 3 & 3 & 3 & 3 & 2 & 2 & 3 & 3 & 3 & 3 & 3 & 3 \\
\hline Total & 3.58 & 3.67 & 3.58 & 3.83 & 4.08 & 4.08 & 4.08 & 4.08 & 2.58 & 2.58 & 2.83 & 3.00 & 4.50 & 4.50 & 4.67 & 4.42 \\
\hline
\end{tabular}

was found that the reduction in sodium chloride mass fraction caused an increased yeast activity, and thus higher $\mathrm{CO}_{2}$ production. Moreover, when the mass fraction of sodium chloride was reduced, the retention coefficient (measurement of the capability of a dough to retain gas) was found to be significantly lower. However, these changes did not affect the quality of the bread, e.g. specific volume, bake loss or moisture loss. In final conclusions, the authors found that dough rheology properties, baking quality characteristics and sensory attributes of bread loaves produced with 0.3 and $0.6 \%$ sodium chloride were almost the same as the control sample with $1.2 \%$ of sodium chloride. Wehrle et al. (28), analysing the effect of the addition of sodium chloride (3\%) on fundamental rheological properties of wheat dough, showed that dough with sodium chloride was characterised by a threefold increase in resistance to extension compared to saltless dough. On the other hand, Preston (29), examining the effects of neutral salts of the lyotropic series on the physical properties of a dough made from the flour of Canadian red spring wheat variety, reported that samples with 0.3 , $0.5,0.75$ and $1.0 \%$ of sodium chloride were characterised by a decrease in dough strength properties and increase in water absorption mesured with a farinograph. Toyosaki and Sakane (30) examined the effect of sodium chloride addition on wheat dough fermentation and showed that it increased gluten-forming ability during dough fermentation and contributed to peroxidation of lipids catalysed by baker's yeast, resulting in the formation of hydroperoxides, which enhance the dough fermentation. In addition, Kawai et al. (31) showed that the fermentation activity of yeast is stimulated in the dough with small mass fractions of sodium chloride (up to $2 \%$ ). In samples with higher mass fraction of sodium chloride, the decrease in leavening ability was observed.

\section{Conclusions}

Wheat bread made from white flour can be baked without sodium chloride addition using each of the techniques of dough preparation, because its yield is similar to that of bread made with a commonly used mass fraction of sodium chloride $(1.5 \%)$, but its volume is larger and palatability better, while crumb firmness is the same for natural starter sourdough or better when yeast is used. On the other hand, wheat bread from wholemeal flour can be made without sodium chloride addition only when the dough is prepared from natural sourdough or starter sourdough. Rye bread from white flour can be produced with a mass fraction of sodium chloride reduced to $1 \%$ only when prepared with yeast or with natural sourdough. In case of rye bread made from wholemeal flour, it was found that this type of bread can be made without sodium chloride addition only when using yeast, whereas the addition of sodium chloride can be reduced to $1 \%$ when dough is made with natural sourdough or starter sourdough.

\section{References}

1. Dewettinck K, Van Bockstaele F, Kühne B, Van de Walle D, Courtens TM, Gellynck X. Nutritional value of bread: influence on processing, food interaction and consumer perception. J Cereal Sci. 2008;48:243-57.

http://dx.doi.org/10.1016/j.jcs.2008.01.003

2. Quilez J, Salas-Salvado J. Salt in bread in Europe: potential benefits of reduction. Nutr Rev. 2012;70:666-78. http://dx.doi.org/10.1111/j.1753-4887.2012.00540.x

3. Dietary reference intakes: water, potassium, sodium, chloride, and sulfate. Report of the Institute of Medicine, National Academy of Medicine, USA. United States Institute of Medicine. Washington, D.C., USA: The National Academies 
Press; 2004. Available from: http://www.nap.edu/read/10925/ chapter/1\#ii.

4. Doyle ME. Understanding sodium replacements from safety and health risk perspective. Madison, WI, USA: Food Research Institute, University of Wisconsin; 2011. Available from: http://www.namif.org/wp-content/uploads/09-406.pdf.

5. Brown IJ, Tzoulaki I, Candeias V, Elliott P. Salt intakes around the world: implications for public health. Int J Epidemiol. 2009;38:791-813. http://dx.doi.org/10.1093/ije/dyp139

6. European Food Safety Authority (EFSA). Opinion of the scientific panel on dietetic products, nutrition and allergies on a request from the commission related to the tolerable upper intake level of sodium. EFSA J. 2005;209:1-26. http://dx.doi.org/10.2903/j.efsa.2004.59

7. Survey on members states' implementation of the EU salt reduction framework. European Commission Report. Brussels, Belgium: European Commission; 2012. Available from: http://ec.europa.eu/health/nutrition_physical_activity/docs/ salt_report1_en.pdf.

8. Luchian MI, Canja CM. Effect of salt on gas production in bread dough. Bull Trans Univ Brasov. 2010;3:167-70.

9. Lynch EJ, Dal Bello F, Sheehan EM, Cashman KD, Arendt EK. Fundamental studies on the reduction of salt on dough and bread characteristics. Food Res Int. 2009;42:885-91. http://dx.doi.org/10.1016/j.foodres.2009.03.014

10. Salovaara H. Technologies of salt reduction in bread: issues, problems and solutions. In: Salt in bread: technical, taste and other parameters for healthy eating: CCAB Seminar. Brussels, Belgium: Centre de Conferences Albert Borschette (CAAB); 2009.

11. He FJ, Burnier M, MacGregor GA. Nutrition in cardiovascular disease: salt in hypertension and heart failure. Eur Heart J. 2011;32:3073-80. http://dx.doi.org/10.1093/eurheartj/ehr194

12. Mhurchu CN, Capelin C, Dunford EK, Webster JL, Neal BC, Jebb SA. Sodium content of processed foods in the United Kingdom: analysis of 44,000 foods purchased by 21,000 households. Am J Clin Nutr. 2011;93:594-600. http://dx.doi.org/10.3945/ajcn.110.004481

13. Castanheira I, Figueiredo C, André C, Coelho I, Silva AT, Santiago S, et al. Sampling of bread for added sodium as determined by flame photometry. Food Chem. 2009;113:621-8. http://dx.doi.org/10.1016/j.foodchem.2008.07.047

14. Bolhuis DP, Temme EHM, Koeman FT, Noort MWJ, Kremer S, Janssen MA. A salt reduction of $50 \%$ in bread does not decrease bread consumption or increase sodium intake by the choice of sandwich fillings. J Nutr. 2011;141:2249-55. http://dx.doi.org/10.3945/jn.111.141366

15. Dötsch M, Busch J, Batenburg M, Liem G, Tareilus E, Müller R, Meijer G. Strategies to reduce sodium consumption: a food industry perspective. Crit Rev Food Sci Nutr. 2009;49: 841-51. http://dx.doi.org/10.1080/10408390903044297

16. Girgis S, Neal B, Prescott J, Prendergast J, Dumbrell S, Turner $\mathrm{C}$, Woodward $\mathrm{M}$. A one-quarter reduction in the salt con- tent of bread can be made without detection. Eur J Clin Nutr. 2003;57:616-20.

http://dx.doi.org/10.1038/sj.ejcn.1601583

17. Noort MWJ, Bult JHF, Stieger M, Hamer RJ. Saltiness enhancement in bread by inhomogeneous spatial distribution of sodium chloride. J Cereal Sci. 2010;52:378-86.

http://dx.doi.org/10.1016/j.jcs.2010.06.018

18. ISO 712:2009. Cereals and cereal products - Determination of moisture content - Routine reference method. Geneva, Switzerland: International Organization for Standarization (ISO); 2009.

19. Gould JM, Jasberg BK, Cote GL. Structure-function relationships of alkaline-peroxide treated lignocellulose from wheat straw. Cereal Chem. 1989;66:213-7.

20. ISO 3093:2009. Wheat, rye and respective flours, durum wheat semolina - Determination of the falling number according to Hagberg-Perten. Geneva, Switzerland: International Organization for Standarization (ISO); 2009.

21. ISO 21415-2:2006. Wheat and wheat flour - Gluten content, Part 2: Determination of wet gluten by mechanical means. Geneva, Switzerland: International Organization for Standarization (ISO); 2006.

22. ISO 5529:2007. Wheat - Determination of the sedimentation index - Zeleny test. Geneva, Switzerland: International Organization for Standarization (ISO); 2007.

23. Greene JL, Bovell-Benjamin AC. Macroscopic and sensory evaluation of bread supplemented with sweet-potato flour. J Food Sci. 2004;69:167-73.

http://dx.doi.org/10.1111/j.1365-2621.2004.tb06359.x

24. Majewska K, Dąbkowska E, Żuk-Gołaszewska K, Tyburski J. Baking quality of flour obtained from grain of chosen spelt varieties (Triticum spelta L.). Zywn-Nauk Technol Ja. 2007;2:60-71 (in Polish).

25. Che Pa NF, Chin NL, Yusof YA, Aziz NA. Measurement of bread crumb texture via imaging of its characteristics. J Food Agric Environ. 2013;11:48-55.

26. Watts BM, Ylimaki GL, Jeffrey LSE, Elias LG. Sensory tests: Descriptions and applications. Basic sensory methods for food evaluation. International Development Research Centre; Ottawa, Ontario, Canada; 1989. pp. 68-79.

27. STATISTICA, v. 10, StatSoft Polska Sp. ZO.O. Cracow, Poland. 2012. Available from: http://www.statsoft.com.

28. Wehrle K, Grau H, Arendt EK. Effects of lactic acid, acetic acid, and table salt on fundamental rheological properties of wheat dough. Cereal Chem. 1997;74:739-44. http://dx.doi.org/10.1094/CCHEM.1997.74.6.739

29. Preston KR. Effects of neutral sodium chlorides of the lyotropic series on the physical dough properties of a Canadian red spring wheat flour. Cereal Chem. 1989;66:144-8.

30. Toyosaki T, Sakane Y. Effects of salt on wheat flour dough fermentation. Adv J Food Sci Technol. 2013;5:84-9.

31. Kawai H, Bagum N, Teramoto A, Isobe U, Yokoigawa $\mathrm{K}$. Effects of sodium chloride on the growth and fermentation activity of Saccharomyces yeasts. Res J Living Sci. 1999;45: 55-61. 